\title{
Ocena zgodności przyrządów pomiarowych na podstawie specyfikacji zharmonizowanych (normy EN i zalecenia OIML) oraz innych dokumentów
}

\begin{abstract}
W artykule przedstawiono różne możliwości oceny zgodności gazomierzy z wymaganiami dyrektywy MID przy użyciu norm europejskich, zaleceń OIML oraz innych dokumentów. Pokazano różnice w podejściach zawartych w normach europejskich i zaleceniach OIML w zakresie warunków do przeprowadzenia badania typu oraz zalety i wady każdego z podejść. Przeprowadzono analizę ryzyka.
\end{abstract}

Słowa kluczowe: gazomierze, ocena zgodności, dyrektywa MID.

\section{The conformity assessment of measuring instruments based on harmonized specifications (EN standards and OIML recommendation) and other documents}

\begin{abstract}
This paper presents various options of conformity assessment of gas meters with MID directive requirements using European standards, OIML recommendations and other documents. The article shows the differences in approach of European standards and OIML recommendations in the scope of conditions for the type of examination as well as the advantages and disadvantages of each approach. A risk assessment is done.
\end{abstract}

Key words: gas meters, conformity assessment, MID directive.

\section{Wprowadzenie}

Ocena zgodności jest procesem poprzedzającym wprowadzenie produktu na rynek i oznacza działanie polegające na wykazaniu, że określony wyrób i proces jego produkcji są zgodne z wymaganiami określonymi w przepisach prawnych. System oceny zgodności wyrobów ma zagwarantować dopuszczenie do obrotu na jednolitym rynku Unii Europejskiej (UE) tylko tych spośród nich, które spełniają wymagania unijnych aktów prawnych, dotyczących głównie aspektów bezpieczeństwa użytkowania produktów. System oparty jest na aktach prawnych krajowych własnych i krajowych będących transpozycją prawa unijnego (są to głównie dyrektywy tzw. starego, nowego i globalnego podejścia). Zgodnie z zasadami dyrektyw nowego podejścia ocena wyrobów dotyczy tylko wymagań zasadniczych, przez które rozumie się wymagania w zakresie cech wyrobu, jego projektowania lub wytwarzania, określone w odpowiednich dyrektywach [3]. W przypadku urządzeń i systemów z funkcjami pomiarowymi (za wyjątkiem wag nieautomatycznych) ocena zgodności powinna być realizowana zgodnie z dyrektywą metrologiczną 2004/22/WE [4]. Dyrektywa 2004/22/WE (w skrócie MID - od Measuring Instruments Directive) należy do grupy dyrektyw nowego podejścia wdrażających system oceny zgodności, zastępujący dotychczasowy system prawnej kontroli metrologicznej, w zakresie zatwierdzania typu i legalizacji pierwotnej.

Najprostszym sposobem wykazania zgodności wyrobu z wymaganiami zasadniczymi dyrektywy jest potwierdzenie zgodności z normą zharmonizowaną z dyrektywą lub specyfikacją zharmonizowaną z dyrektywą. Specyfikacje zharmonizowane z dyrektywą metrologiczną (zdefiniowane w ustawie z dnia 30 sierpnia 2002 r. o systemie oceny zgodności [22] jako „specyfikacje techniczne uzgodnione międzynarodowo”) to dokumenty normatywne Międzynarodowej Organizacji 
Metrologii Prawnej (International Organization of Legal Metrology, OIML). Obie wymienione drogi prowadzą do tego samego celu, jakim jest wykazanie zgodności z wymaganiami zasadniczymi dyrektywy, różnią się jednak w niektórych miejscach wymaganiami technicznymi, metodyką badań oraz oceną ich wyników.

Należy zaznaczyć, że 18 kwietnia 2014 r. weszła w życie dyrektywa 2014/32/UE [5], zwana potocznie przekształconą dyrektywą metrologiczną. Jest ona adresowana do państw członkowskich UE, które zobowiązane są do wdrożenia tej dyrektywy do ustawodawstwa krajowego do 19 kwietnia 2016 r., kiedy obecnie obowiązująca dyrektywa 2004/22/WE straci moc. Certyfikaty na mocy uchylonej dyrektywy pozostaną ważne do końca wskazanego na nich okresu ważności. Przekształcona dyrektywa 2014/32/UE będzie obowiązywać od 20 kwietnia $2016 \mathrm{r}$.
Jedną ze zmian w przekształconej dyrektywie metrologicznej 2014/32/UE jest ujednolicenie z innymi dyrektywami nowego podejścia definicji i ról pełnionych przez podmioty gospodarcze na rynku przyrządów pomiarowych, takich jak producent, upoważniony przedstawiciel, importer czy dystrybutor. Duży nacisk położono na zachowanie zgodności przyrządów pomiarowych z określonymi w dyrektywie wymaganiami zasadniczymi i na zapewnienie bezpieczeństwa. Obowiązki w tym zakresie nałożono zarówno na producentów, jak i na importerów oraz dystrybutorów przyrządów pomiarowych. Nowe ramy prawne nakładają na importerów szereg obowiązków, bardzo zbliżonych do obowiązków nakładanych na producentów. Wymagania dotyczące procedur badania typu WE gazomierzy i przeliczników do gazomierzy zawarte w przekształconej dyrektywie 2014/32/UE nie uległy zmianie.

\section{Ocena zgodności w wybranych krajach Unii Europejskiej}

Dyrektywy nowego podejścia są skierowane do państw członkowskich UE, które mają obowiązek ich implementacji do swoich przepisów krajowych. Przepisów dyrektyw w państwach członkowskich nie stosuje się bezpośrednio, ale akty prawne przenoszące dyrektywy na grunt prawa krajowego zawsze zawierają odesłanie pozwalające stwierdzić, którą dyrektywę wdraża dana ustawa czy rozporządzenie. Takie odesłanie znajduje się także w polskich przepisach implementujących dyrektywę metrologiczną.

Artykuł 2, ustęp 1 dyrektywy metrologicznej [4] („Państwa Członkowskie mogą nakazać”) nie nakłada obligatoryjnie stosowania przepisów dyrektywy MID przez kraje Unii Europejskiej. Jednakże w przypadku, kiedy dane państwo członkowskie nie wprowadzi wymagań dyrektywy MID do swojego prawodawstwa, powinno poinformować o przyczynach takiego stanu Komisję Europejską oraz inne kraje Unii Europejskiej (artykuł 2, ustęp 2 dyrektywy MID). Wobec powyższego w różnych krajach UE mogą być stosowane różne podejścia w zakresie oceny zgodności przyrządów pomiarowych. Kolejny zapis w punkcie 6 preambuly dyrektywy metrologicznej [4] mówi, że „Zasadę fakultatywności wprowadzoną niniejszą dyrektywą, według której Państwa Członkowskie mogą wykonywać swoje prawo decydowania o regulacji wszelkich przyrządów objętych niniejszą dyrektywą, należy stosować jedynie w takim zakresie, w jakim nie spowoduje to nieuczciwej konkurencji". Zapis ten pozwala na uznaniowe stosowanie przepisów dyrektywy w poszczególnych krajach, a jedynym ograniczeniem stosowania „zasady fakultatywności” jest niespowodowanie nieuczciwej konkurencji.

W Wielkiej Brytanii ocena zgodności oraz prawna kontrola metrologiczna są ograniczone do gazomierzy stosowanych przy pomiarach nieprzekraczających $1600 \mathrm{~m}^{3} / \mathrm{h}$ (w warunkach ciśnienia 1013,25 mbar i temperatury $15^{\circ} \mathrm{C}$ ). Takie podejście ma uzasadnienie historyczne. Gazomierze wykorzystywane przy poborach przekraczających $1600 \mathrm{~m}^{3} / \mathrm{h}$ podlegają wewnętrznym wymaganiom operatora przesyłowego w ramach porozumień handlowych zawartych pomiędzy zainteresowanymi stronami.

W Niemczech ocena zgodności nie została ograniczona wielkością gazomierzy. Gazomierze wprowadzane do obrotu i użytkowania powinny spełniać zasadnicze wymagania dyrektywy MID lub posiadać krajowe zatwierdzenie typu. Wymagania dyrektywy MID są obligatoryjne dla gazomierzy wykorzystywanych w gospodarstwach domowych, handlu i przemyśle lekkim, niemniej jednak nie zostały określone definicje tych obszarów. Dlatego też stosowanie przepisów MID w przypadku przemysłu ciężkiego jest możliwe, ale nie jest przymusowe.

W Holandii wszystkie gazomierze powyżej zużycia wynoszącego $170000 \mathrm{~m}^{3} /$ rok nie podlegają prawnemu systemowi kontroli metrologicznej. We Włoszech (podobnie jak w Niemczech i w Czechach) nowe gazomierze wprowadzane do obrotu i użytkowania powinny posiadać certyfikat MID, bez wskazania ograniczenia co do wielkości i rodzaju gazomierza.

Każde z wymienionych państw wdrożyło postanowienia dyrektywy MID do prawa krajowego. W poszczególnych krajach istnieją jednak różnice pomiędzy interpretacją obszaru zastosowania przepisów dyrektywy „do użytku domowego, w usługach i handlu oraz w przemyśle drobnym". Stanowi to powód wprowadzenia przez niektóre kraje (np. Wielka Brytania, Holandia) ograniczeń wielkości gazomierzy 
objętych oceną zgodności z zasadniczymi wymaganiami dyrektywy MID.

W Polsce dyrektywa metrologiczna została zaimplementowana do prawodawstwa krajowego poprzez ustawę z dnia 15 grudnia 2006 r. o zmianie ustawy o systemie oceny zgodności oraz zmianie niektórych innych ustaw [20] i rozporządzenie Ministra Gospodarki z dnia 18 grudnia 2006 r. w sprawie zasadniczych wymagań dla przyrządów pomiarowych [18], zmienione następnie przez rozporządzenie Ministra Gospodarki z dnia 16 sierpnia 2010 r. [17]. Dyrektywa MID została również wprowadzona do ustawy - Prawo o miarach [19] po- przez ustawę z dnia 27 maja 2004 r. o zmianie ustawy - Prawo o miarach [21].

Zgodnie z punktem 1.1 załącznika 2 do rozporządzenia Ministra Gospodarki z dnia 18 grudnia 2006 r. [18] zasadnicze wymagania dla przyrządów pomiarowych określone w rozporządzeniu wraz z zasadniczymi wymaganiami określonymi w załączniku 2 stosuje się do gazomierzy i przeliczników do gazomierzy przeznaczonych do stosowania $\mathrm{w}$ gospodarstwach domowych, usługach i handlu oraz w przemyśle drobnym. W Polsce nie wprowadzono ograniczeń wielkości gazomierzy objętych oceną zgodności z zasadniczymi wymaganiami dyrektywy MID.

\section{Normy zharmonizowane z dyrektywą MID}

Normy zharmonizowane z dyrektywą metrologiczną w zakresie badań gazomierzy miechowych (PNEN 1359:2004+A1:2006 [13]), domowych ultradźwiękowych (PN-EN 14236:2010 [14]), turbinowych (PN-EN 12261:2005+A1:2008 [9]) i rotorowych (PNEN 12480:2005+A1:2008 [12]) określają warunki pracy oraz wymagania i badania odnośnie do konstrukcji, właściwości metrologicznych, a także bezpieczeństwa użytkowania gazomierzy. Normy te definiują klasy metrologiczne gazomierzy, rodzaj paliw gazowych, maksymalne ciśnienia robocze, rzeczywiste strumienie objętości gazu, a także zakresy temperatur otoczenia i gazu. Norma dotycząca przeliczników do gazomierzy PN-EN 12405-1+A2:2010 [10] określa wymagania i badania odnośnie do budowy, właściwości metrologicznych, bezpieczeństwa i zgodności elektronicznych urządzeń do przeliczania objętości gazu, które są dołączane do gazomierzy, stosowanych do pomiaru objętości paliw gazowych z pierwszej i drugiej rodziny gazu. Norma uwzględnia urządzenia z przeliczaniem typu T, PT lub PTZ.

\section{Specyfikacje zharmonizowane z dyrektywą MID}

Jak już wspomniano, specyfikacje zharmonizowane $\mathrm{z}$ dyrektywą metrologiczną to dokumenty normatywne Międzynarodowej Organizacji Metrologii Prawnej. W przypadku gazomierzy specyfikacją zharmonizowaną z dyrektywą MID są zalecenia OIML R 137-1\&2:2012 [23]. Powiązanie zgodności tych zaleceń z zasadniczymi wymaganiami dyrektywy metrologicznej jest zamieszczone w komunikacie Komisji Europejskiej w ramach wykonania dyrektywy 2004/22/WE Parlamentu Europejskiego i Rady w sprawie przyrządów pomiarowych z dnia 14 marca 2014 r. [6]. Dla przeliczników do gazomierzy są to zalecenia OIML R 140:2007. Powiązanie zgodności zaleceń dla przeliczników jest zamieszczone z kolei w komunikacie Komisji Europejskiej w ramach wykonania dyrektywy 2004/22/WE Parlamentu Europejskiego i Rady w sprawie przyrządów pomiarowych z dnia 10 listopada 2009 r. [7].

Międzynarodowa Organizacja Metrologii Prawnej, której Polska jest członkiem, to organizacja międzyrządowa z siedzibą w Paryżu utworzona w 1955 r. w celu promowania globalnej harmonizacji procedur metrologii prawnej, które są podstawą ułatwienia handlu międzynarodowego. Gwarantuje to, że certyfikacja urządzeń pomiarowych w jednym kraju będzie zgodna z certyfikacją realizowaną w innych krajach, co w znacznym stopniu ułatwia handel urządzeniami pomiarowymi. Od momentu swojego powstania organizacja ta przygotowała szereg wytycznych dotyczących pomocy dla swoich członków w celu opracowania odpowiedniego prawodawstwa w zakresie metrologii we wszystkich aspektach życia społecznego i wytycznych w sprawie oceny zgodności i wymagań dla nowych produktów.

Zalecenia OIML R 137-1\&2:2012 to uniwersalny dokument normatywny, który dotyczy każdego typu gazomierzy działających na dowolnej zasadzie używanych do pomiaru ilości gazu w jednostkach objętości lub masy. Przedmiotem zaleceń OIML są gazomierze zarówno z liczydłami mechanicznymi, elektromechanicznymi, elektronicznymi, jak i z kombinacją takich liczydeł. Zalecenia te nie ograniczają wprowadzania do obrotu nowych rozwiązań urządzeń do pomiarów gazu, a także są bardzo liberalne w zakresie ustalania parametrów tych przyrządów pomiarowych $\left(Q_{\min }, Q_{\max }, P_{\min }\right.$, $\left.P_{\max }\right)$, oczywiście przy zapewnieniu ich właściwości metrologicznych. W odróżnieniu od norm europejskich dotyczących gazomierzy zalecenia OIML precyzują jedynie minimalne wymagania odnoszące się do bezpieczeństwa użytkowania oraz niektórych parametrów technicznych, np. odporności na korozję, i skupiają się głównie na właściwościach metrologicznych gazomierzy. 
W przypadku gazomierzy wyprodukowanych do września 2014 r. aktualny był dokument R 137-1:2006 [24], jednak harmonizacja tego wydania $\mathrm{z}$ dyrektywą MID została wycofana komunikatem Komisji Europejskiej z dnia 14 marca 2014 r. [8] po upływie 180 dni od daty jego publikacji.
Świadectwa badania typu WE wydane na podstawie wspomnianego dokumentu normatywnego przed jego wycofaniem zachowują ważność do upływu terminu swej ważności bez żadnych ograniczeń we wprowadzaniu do obrotu lub użytkowaniu.

\section{Inne dokumenty}

Zgodność przyrządów pomiarowych z zasadniczymi wymaganiami dyrektywy metrologicznej można wykazać również przy pomocy innych dokumentów, niezharmonizowanych z dyrektywą. Są to tzw. inne dokumenty, zdefiniowane w dyrektywie MID w punkcie 13 preambuły jako ,specyfikacje niezawarte w europejskich normach technicznych lub w dokumentach normatywnych uzgodnionych międzynarodowo" oraz w artykule 13 punkcie 2 ustawy o systemie oceny zgodności: „W przypadku gdy producent lub jego upoważniony przedstawiciel nie wykaże zgodności wyrobu z odpowiednimi postanowieniami norm zharmonizowanych lub specyfikacji zharmonizowanych, jest obowiązany wykazać zgodność wyrobu z zasadniczymi wymaganiami na podstawie innych dowodów". Zapis dyrektywy metrologicznej 2004/22/WE pozwala tutaj stosować inne specyfikacje techniczne do oceny zgodności gazomierzy. Inną specyfikacją może być dowolny dokument określający wymagania i badania dla gazomierzy i przeliczników do gazomierzy lub zastosowanych w nich rozwiązań technicznych, jeżeli tylko z jego pomocą jest możliwe wykazanie zgodności z zasadniczymi wymaganiami dyrektywy metrologicznej.

Przykładem „innych dokumentów” mogą być normy europejskie niezharmonizowane $\mathrm{z}$ dyrektywą, normy międzynarodowe ISO, normy krajowe lub normy branżowe określające wymagania i badania dla gazomierzy, jeżeli obejmują (w całości lub w części) wymagania zasadnicze dyrektywy metrologicznej. Formalnie do chwili ogłoszenia harmonizacji normy PN-EN 12480:2015 Gazomierze. Gazomierze rotorowe [11] przez Komisję Europejską normy tej można użyć do oceny zgodności gazomierzy wyłącznie jako innej specyfikacji.

Ocenę zgodności na podstawie innych specyfikacji przeprowadza się w analogiczny sposób jak w przypadku dokumentów zharmonizowanych, przy czym podczas oceny należy potwierdzić zgodność wybranego dokumentu normatywnego z wymaganiami zasadniczymi dyrektywy metrologicznej.

Przykładami niezharmonizowanych z dyrektywą metrologiczną norm europejskich i międzynarodowych dotyczących badań gazomierzy są:

1. PN-ISO 17089-1:2013 Pomiar przeplywu plynu w przewodach zamkniętych. Gazomierze ultradźwiękowe. Część 1:
Gazomierze do pomiarów rozliczeniowych i bilansowych [16],

2. PN-EN 12480:2015 Gazomierze. Gazomierze rotorowe [11],

3. PN-EN 16314:2013 Gazomierze. Dodatkowe funkcjonalności [15].

Pierwsza z wymienionych norm dotyczy gazomierzy ultradźwiękowych do pomiarów rozliczeniowych i bilansowych, które wykorzystują czas przejścia sygnałów akustycznych do pomiaru przepływu jednofazowych jednorodnych gazów w przewodach zamkniętych. Druga - to najnowsza wersja normy dla gazomierzy rotorowych, która w niedługim czasie zostanie zharmonizowana $\mathrm{z}$ dyrektywą metrologiczną. Najważniejsze zmiany w normie PN-EN 12480:2015 to rozszerzenie zakresu ciśnienia roboczego gazomierzy do 20 bar oraz wymaganie odnośnie do niepewności rozszerzonej wyników badań (1/5 MPE podczas badania typu (moduł B) oraz 1/3 MPE podczas oceny zgodności (moduły D i F, w tym kontroli wyrobu gotowego moduł H1)). Ostatnia, trzecia norma określa dodatkowe wymagania i badania dla gazomierzy miechowych, turbinowych i rotorowych oraz gazomierzy domowych ultradźwiękowych, które posiadają zasilane bateryjnie urządzenia rozszerzające ich funkcjonalność (np. wbudowany zawór) oraz posiadających elektroniczne liczydło. Niestety w zakresie jej stosowania zawężono maksymalny strumień objętości gazomierzy do $40 \mathrm{~m}^{3} / \mathrm{h}$ (w przypadku gazomierzy z wbudowanym zaworem maksymalny strumień objętości gazomierzy wynosi $10 \mathrm{~m}^{3} / \mathrm{h}$ ) i maksymalne ciśnienie robocze do 500 mbar, co znacznie ogranicza możliwość jej wykorzystania.

Powyższe normy można obecnie stosować do oceny zgodności wyłącznie jako tzw. inne specyfikacje. Przy czym dla normy PN-EN 12480:2015 w załączniku harmonizującym ZA zostało wykazane powiązanie z zasadniczymi wymaganiami dyrektywy metrologicznej i jest tylko kwestią czasu ogłoszenie jej harmonizacji przez Komisję Europejską w Dzienniku Urzędowym UE. Natomiast w przypadku normy PN-ISO 17089-1:2013 producent musiałby wykazać, a jednostka notyfikowana potwierdzić, że zastosowanie tej normy pozwoli domniemywać o zgodności wyrobu z zasadniczymi wymaganiami dyrektywy MID. 


\section{Różnice w podejściu norm i zaleceń OIML na przykładzie badania typu WE gazomierzy}

\section{Wymagania dla stanowiska badawczego}

Normy PN-EN 1359 i PN-EN 12480:2005+A1:2008 zawierają tylko minimalne wymagania w zakresie czynnika pomiarowego oraz warunków badań i nie formułują żadnych wytycznych odnośnie do niepewności wyników pomiarów uzyskiwanych na stanowisku do badania właściwości metrologicznych gazomierzy. Jednak już w nowej normie dotyczącej badań gazomierzy rotorowych PN-EN 12480:2015 [11] wprowadzono następujące wymagania: „Niepewność stanowiska badawczego powinna wynosić nie więcej niż 1/5 maksymalnego błędu dopuszczalnego MPE podczas oceny zgodności (moduł B) oraz nie więcej niż 1/3 MPE dla oceny zgodności (moduły D i F, w tym inspekcji produktu końcowego moduł H1)".

Norma PN-EN 12261:2005+A1:2008 podaje krótką charakterystykę: stanowiska do badań w zakresie czynnika pomiarowego (powietrze lub gaz ziemny), szczelności stanowiska badawczego, warunków instalacji gazomierza na stanowisku pomiarowym oraz wymaganych wzorców odniesienia. Norma wskazuje również wymaganą niepewność wyników badań: „Niepewność rozszerzona badań powinna być poniżej $1 / 3$ błędu dopuszczalnego granicznego".

Z kolei w zaleceniach OIML R 137-1\&2:2012 określono, że niepewność rozszerzona podczas wyznaczania błędów wskazań (przy prawdopodobieństwie rozszerzenia wynoszącym około 95\%) podczas badania typu gazomierzy powinna być mniejsza niż 1/5 MPE oraz mniejsza niż 1/3 MPE dla sprawdzania gazomierzy (weryfikacji jednostkowej). Zalecenia OIML dopuszczają jednak odstępstwo od wyżej wymienionego warunku. Jeżeli wymagane wartości niepewności nie są spełnione, należy wówczas zredukować błędy graniczne dopuszczalne MPE.

\section{Warunki pracy gazomierzy}

Normy zharmonizowane w zakresie gazomierzy miechowych, turbinowych i rotorowych podają bardzo szczegółowo wartości maksymalnych i minimalnych strumieni gazu, zakresowość gazomierzy oraz wartości strumieni przejściowych gazu $Q_{t}$. Zalecenia OIML, z uwagi na bardziej uniwersalny charakter, określają tylko granice ilorazu maksymalnego i minimalnego strumienia objętości i odpowiadające im wartości maksymalne strumienia przejściowego $Q_{t}$. Tak więc wartości te mogą być bardziej dowolnie definiowane przez producentów, a zalecenia OIML podają tylko ich wartości graniczne.

Wartości deklarowanych temperatur gazu i otoczenia w normach i zaleceniach OIML są zbliżone, przy czym zalecenia OIML zawierają dodatkowo temperaturę $+5^{\circ} \mathrm{C}$ dla dolnej granicy temperatury $\mathrm{i}+30^{\circ} \mathrm{C}$ dla górnej granicy. Zalecenia OIML nie określają wymagań co do minimalnego zakresu temperatury gazu.

\section{Strumienie podczas badań}

Wartości strumieni objętości gazu, które należy stosować podczas badań w normach europejskich, podawane są jako wielokrotność (ułamek dziesiętny lub procent) minimalnego $Q_{\text {min }}$ lub maksymalnego strumienia objętości gazu $Q_{\max }$ i są to generalnie wartości stałe. Stała jest również liczba punktów pomiarowych. Natomiast w przypadku zaleceń OIML liczbę punktów pomiarowych oraz strumienie objętości, przy których należy przeprowadzić badania błędów wskazania gazomierzy, należy obliczyć z odpowiednich zależności.

\section{Ciśnienia stosowane podczas badań}

Podczas badań gazomierzy objętościowych zgodnie z PN-EN 1359:2004+A1:2006 i PN-EN 12480:2005+A1:2008 w przypadku gazomierzy o maksymalnym ciśnieniu roboczym określonym w zakresie wyżej wymienionych norm (dla gazomierzy miechowych: 0,5 bar, a dla gazomierzy rotorowych: 16 bar lub 20 bar, zgodnie z najnowszym, niezharmonizowanym wydaniem normy PN-EN 12480:2015) wszystkie badania błędów wskazań należy wykonać przy ciśnieniu atmosferycznym.

Według PN-EN 12261:2005+A1:2008 podczas wyznaczania błędu wskazania gazomierzy turbinowych przeznaczonych do użytkowania w zakresie ciśnień roboczych do 4 bar włącznie - badania należy przeprowadzić w warunkach atmosferycznych, a w przypadku gazomierzy przeznaczonych do użytkowania w zakresie ciśnień powyżej 4 bar badania błędu wskazania należy wykonać przy co najmniej ciśnieniu minimalnym i maksymalnym, podanym przez producenta. Gdy ciśnienie maksymalne przekracza 50 bar, dopuszcza się badanie gazomierzy przy ciśnieniu 50 bar. Pozostałe badania metrologiczne oraz badania po narażeniach gazomierzy (np. przeciążenie, odporność na moment zginający i skręcający, trwałość) należy wykonywać w różnych warunkach ciśnienia - od ciśnienia atmosferycznego do maksymalnego ciśnienia roboczego (50 bar) [1].

Zgodnie z OIML R 137-1\&2:2012 gazomierze powinny spełnić wymagania w całym zakresie ciśnienia. Błąd wskazania należy wyznaczyć co najmniej przy minimalnym i maksymalnym ciśnieniu roboczym, przy czym od reguły tej istnieje wyjątek: „Dla technologii, które okazały się niewrażliwe na ciśnienie oraz gazomierzy miechowych badanie to nie jest stosowane". Zapis ten pozostawia możliwość badania gazomierzy przy ciśnieniu atmosferycznym (w ograniczonych 
zakresach ciśnienia roboczego) lub minimalnym ciśnieniu roboczym.

Zalecenia OIML R 137-1\&2:2012 nie precyzują jednak kryteriów, kiedy można uznać, że gazomierz czy typoszereg gazomierzy jest niewrażliwy na ciśnienie. Dlatego powyższy zapis może być różnie interpretowany przez jednostki notyfikowane.

\section{Maksymalne dopuszczalne błędy graniczne MPE i strata ciśnienia}

Dopuszczalne błędy graniczne wynikają z wymaganych klas przyrządów przewidzianych w metrologii prawnej. Normy przedmiotowe w zakresie gazomierzy narzucają obligatoryjnie klasy gazomierzy: dla gazomierzy miechowych klasę 1,5, natomiast dla gazomierzy turbinowych i rotorowych klasę 1,0. Z kolei zalecenia OIML wymieniają 3 klasy gazomierzy: klasę 0,$5 ; 1,0$ i 1,5 - bez sprecyzowania, jakich typów gazomierzy dotyczą. W przypadku oceny zgodności klasa gazomierzy jest ograniczona przez zapis dyrektywy metrologicznej, która przewiduje dla gazomierzy klasy nie gorsze niż 1,0 i 1,5 i zawęża stosowanie klas dokładności w zależności od zakresowości gazomierzy. Specyfikacja OIML R 137-1\&2:2012 pozwala zatem na ocenę zgodności z dyrektywą MID gazomierzy o klasie dokładności 1,0 i 1,5 zarówno dla gazomierzy miechowych, jak i rotorowych o zakresie strumieni objętości gazu $Q_{\max } / Q_{\min } \geq 150$, pozwalając rozszerzyć ograniczenia wynikające z norm.

Ponadto w zaleceniach OIML określono, że cała krzywa błędów gazomierza powinna się mieścić w zakresie błędów granicznych dopuszczalnych MPE, w przeciwieństwie do norm, według których wystarczającym warunkiem jest, aby błędy wskazań gazomierza w poszczególnych punktach pomiarowych mieściły się w zakresie dopuszczalnych błędów granicznych. Wymagania odnośnie do średniego błędu ważonego WME są takie same w obydwu dokumentach zharmonizowanych (za wyjątkiem normy PN-EN 1359, która pomija wymagania WME). Z kolei wymagania w zakresie dopuszczalnej maksymalnej straty ciśnienia przy strumieniu maksymalnym $Q_{\max }$ dotyczą wyłącznie norm na gazomierze miechowe i turbinowe, natomiast są pominięte $\mathrm{w}$ normie dotyczącej gazomierzy rotorowych oraz w zaleceniach OIML.

\section{Zalety i wady różnych podejść}

Podstawową zaletą podejścia OIML jest jego uniwersalność, która pozwala na badania wszystkich typów gazomierzy, działających na jakiejkolwiek zasadzie pomiaru, i nie ogranicza nowych rozwiązań technologicznych konstrukcji gazomierzy. Opierając się na zaleceniach OIML, można przeprowadzić badania gazomierzy z liczydłami mechanicznymi, a także elektronicznymi. Jako zaletę podejścia zaleceń zharmonizowanych OIML R 137-1\&2:2012 można również wymienić opracowany przez OIML wzór raportu z badań, OIML R 137-3:2014 [25], standaryzujący raporty z badań, co w przyszłości powinno ułatwić czytelność często bardzo skomplikowanych raportów generowanych przez laboratoria badawcze według własnych wzorów.

Jako wadę podejścia OIML można wskazać mniejszy nacisk na kwestie związane $\mathrm{z}$ bezpieczeństwem użytkowania. Zalecenia OIML określają co prawda podstawowe wymagania w tym zakresie, ale sposób potwierdzenia tych istotnych parametrów gazomierzy pozostawiają do uznania jednostki notyfikowanej. Do wad należy również zaliczyć nie zawsze doprecyzowane zapisy zaleceń OIML R 137-1\&2:2012, np. w przypadku odstępstwa od wymagań wyznaczania błędów wskazań przy minimalnym i maksymalnym ciśnieniu roboczym „dla technologii, które okazały się niewrażliwe na ciśnienie...”. Brak jasnych kryteriów, kiedy można uznać, że gazomierze są niewrażliwe na ciśnienie, może powodować różne interpretacje tych zapisów przez jednostki notyfikowane podczas badania typu WE gazomierzy.

Zaletą podejścia norm europejskich jest to, iż zawierają szczegółowe wymagania i badania w zakresie bezpieczeństwa użytkowania gazomierzy i są w zasadzie gotowymi szablonami pozwalającymi przeprowadzić ocenę typowych gazomierzy.

Z kolei wadą podejścia norm europejskich jest ograniczenie możliwości badania rozwiązań technologicznych nieprzewidzianych przez europejskie dokumenty normalizacyjne. Dotyczy to zarówno nowych rozwiązań, jak i pewnych przyzwyczajeń rynku. Jako wadę podejścia norm europejskich można również wymienić niewielkie wsparcie rozwiązań już istniejących na rynku, np. liczydeł elektronicznych. Obecnie nie ma normy zharmonizowanej z dyrektywą metrologiczną w zakresie oceny gazomierzy mechanicznych z liczydłem elektronicznym, a jednostki notyfikowane są zmuszone $w$ tym obszarze do określenia wymagań na podstawie innych dokumentów [2]. Można w tym przypadku użyć np. normy PN-EN 16314:2013 [15], w której podano między innymi wymagania dla liczydeł elektronicznych. Niestety w zakresie jej stosowania zawężono maksymalny strumień objętości gazomierzy do $40 \mathrm{~m}^{3} / \mathrm{h}$, co znacznie ogranicza możliwość jej wykorzystania. 


\section{Analiza ryzyka}

Jak już wcześniej zasygnalizowano, ocena zgodności na podstawie norm europejskich i zaleceń OILM prowadzi do tego samego celu, jakim jest wykazanie zgodności z wymaganiami zasadniczymi dyrektywy metrologicznej, różni się jednak w niektórych miejscach wymaganiami technicznymi, metodyką badań oraz oceną wyników badań. Oprócz dwóch powyższych dokumentów normatywnych dyrektywa MID pozwala na trzecią drogę oceny zgodności - przy pomocy innych specyfikacji. Producent może więc przy projektowaniu gazomierzy użyć dowolnych specyfikacji, jeżeli tylko mają uzasadnienie techniczne i można za ich pomocą wykazać zgodność z zasadniczymi wymaganiami dyrektywy metrologicznej. Zastosowane rozwiązania techniczne oparte na innych specyfikacjach powinny być oczywiście zaakceptowane przez jednostkę notyfikowaną przeprowadzającą badanie typu WE. Z uwagi na dużą dowolność takich rozwiązań i brak harmonizacji z dyrektywą MID sposób ten jest dosyć ryzykowny zarówno dla producenta, jak i jednostki notyfikowanej (ze względu na możliwość popełnienia błędu przy projektowaniu lub ocenie zgodności) i wiąże się z reguły w wyższymi kosztami przeprowadzenia oceny zgodności. Oznacza to, że producent, który zaprojektuje i wyprodukuje przyrządy pomiarowe, opierając się na dokumencie zharmonizowanym $\mathrm{z}$ dyrektywą metrologiczną, i potwierdzi w badaniu typu WE, że przyrządy spełniają zasadnicze wymagania dyrektywy, nie powinien się obawiać zagrożenia, że np. któryś z urzędów kontrolujących rynek zakwestionuje zgodność tego przyrządu pomiarowego z dyrektywą MID, ponieważ normy i specyfikacje zharmonizowane bezpośrednio odnoszą się do zasadniczych wymagań dyrektywy metrologicznej (poprzez załącznik harmonizujący do normy o symbolu ZA). W przypadku użycia innych specyfikacji istnieje zagrożenie, że takie wymagania mogą zostać zakwestionowane jako niezgodne (w części lub całości) z zasadniczymi wymaganiami dyrektywy metrologicznej. Z tego względu ścieżka oceny zgodności oparta na wykazaniu zgodności z zasadniczymi wymaganiami dyrektywy metrologicznej przy pomocy innych specyfikacji jest stosowana sporadycznie, a jeżeli już jest realizowana, to jako uzupełnienie do wymagań norm i specyfikacji zharmonizowanych (np. w przypadku, gdy dokumenty zharmonizowane nie obejmują jakiegoś rozwiązania technologicznego gazomierza).

Podstawową różnicą w zakresie wymagań i badań dla gazomierzy na potrzeby oceny zgodności z dyrektywą MID jest znacznie mniejszy nacisk zaleceń OIML na względy bezpieczeństwa użytkowania gazomierzy oraz odporności mechanicznej i odporności na warunki środowiskowe konstrukcji gazomierzy w stosunku do norm europejskich. Pod względem metrologicznym zarówno normy europejskie, jak i zalecenia OIML, pomimo różnych podejść, pozwalają na ocenę zgodności gazomierzy z wymaganiami zasadniczymi dyrektywy metrologicznej na podobnym poziomie. W zakresie wymagań metrologicznych należy zwrócić uwagę na sposób przeprowadzania badania błędów wskazań gazomierzy w deklarowanym zakresie temperatury. Zalecenia OIML podają trzy alternatywne metody, z których pierwsza jest nawet bardziej wymagająca niż metody opisane w normach europejskich zharmonizowanych z dyrektywą, natomiast pozostałe dwie są uproszczone i wyznaczone za ich pomocą błędy wskazań mogą nie odzwierciedlać rzeczywistego zachowywania się gazomierzy w różnych temperaturach pracy.

Dodatkowo bardzo ogólne w niektórych przypadkach wymagania zaleceń OIML (np. dotyczące odporności konstrukcji gazomierza, czy brak kryteriów uznania gazomierzy za niewrażliwe na ciśnienie) pozwalają jednostce notyfikowanej na szeroki zakres interpretacji. Może się zatem okazać, że potwierdzenie tych samych wymagań w różnych jednostkach notyfikowanych będzie diametralnie różne.

\section{Podsumowanie}

Ocenę zgodności gazomierzy z wymaganiami zasadniczymi dyrektywy metrologicznej można przeprowadzić na podstawie norm zharmonizowanych z dyrektywą, zaleceń OIML R 137-1\&2:2012 zharmonizowanych z dyrektywą oraz innych dokumentów.

Dyrektywa MID dopuszcza stosowanie rożnych podejść do oceny zgodności przyrządów pomiarowych, włącznie z nieuwzględnianiem jej zapisów. Jednakże w przypadku, kiedy dane państwo członkowskie nie wprowadzi wymagań dyrektywy MID do swojego prawodawstwa, powinno poinformować o przyczynach takiego stanu Komisję Europejską oraz inne kraje UE.

Ustalony w dyrektywie metrologicznej zakres jej obowiązywania w przypadku gazomierzy i przeliczników do gazomierzy odnosi się do przyrządów, które są wykorzystywane „w gospodarstwach domowych, handlu i przemyśle lekkim”. Niestety nie zostały określone definicje tych obszarów. Z powodu różnej interpretacji powyższego zapisu część krajów UE stosuje ocenę zgodności w określonych dziedzinach wymienionych w dyrektywie bez ograniczeń co do wielkości 
gazomierzy, a część wprowadziła ograniczenia wielkości gazomierzy objętych oceną zgodności z zasadniczymi wymaganiami dyrektywy MID.

Wymagania w zakresie stanowiska badawczego ustalone w normach europejskich EN 1359:1998+A1:2006, EN 12261:2002+A1:2006 oraz EN 12480:2002+A1:2006 (EN 12480:2015 po zharmonizowaniu z dyrektywą) i zaleceniach OIML R 137-1\&2:2012 pomimo różnic pozwalają na wykonywanie badań właściwości metrologicznych gazomierzy miechowych, turbinowych i rotorowych na tym samym stanowisku badawczym. Jeśli niepewność wyników badań uzyskanych na danym stanowisku przekracza 1/5 MPE, to podczas oceny wyników badań według zaleceń OIML lub na potrzebę adaptacji wyników do warunków tych zaleceń należy ograniczyć maksymalne dopuszczalne błędy MPE. Każde z możliwych rozwiązań oceny zgodności przy pomocy zharmonizowanych dokumentów normatywnych (norm europejskich i zaleceń OIML) posiada swoje zalety i wady. Podstawową zaletę podejścia OIML stanowi jego uniwersalność, która pozwala na badania wszystkich typów gazomierzy, działających na jakiejkolwiek zasadzie pomiaru, i nie ogranicza nowych rozwiązań technologicznych ich konstrukcji. Jako wadę podejścia OIML można wymienić mniejszy nacisk na kwestie związane $\mathrm{z}$ bezpieczeństwem użytkowania. Zalecenia OIML określają co prawda podstawowe wymagania w tym zakresie, ale sposób potwierdzenia tych istotnych parametrów gazomierzy pozostawiają do uznania jednostki notyfikowanej. Dodatkowo bardzo ogólne niekiedy wymagania zaleceń OIML pozwalają jednostce notyfikowanej na szeroki zakres interpretacji, więc może się okazać, że potwierdzenie tych samych wymagań w różnych jednostkach notyfikowanych będzie diametralnie różne. Jako przykład można tutaj przytoczyć brak określonych kryteriów w zaleceniach OILM wskazujących, kiedy ciśnienie nie ma wpływu na charakterystyki metrologiczne. Niewłaściwa ocena wpływu ciśnienia na właściwości metrologiczne gazomierzy podczas badania typu WE będzie skutkowała nieprawidłową oceną zgodności tych gazomierzy. Z kolei zaletą podejścia norm europejskich jest to, że określają szczegółowe wymagania i badania w zakresie bezpieczeństwa użytkowania gazomierzy i są w zasadzie gotowymi szablonami, które pozwalają przeprowadzić ocenę typowych gazomierzy. Natomiast jako wadę podejścia norm europejskich należy wskazać ograniczenie możliwości badania rozwiązań technologicznych nieprzewidzianych przez europejskie dokumenty normalizacyjne.

Producent może przy projektowaniu gazomierzy użyć dowolnych specyfikacji, jeżeli tylko mają uzasadnienie techniczne i można za ich pomocą wykazać zgodność z zasadniczymi wymaganiami dyrektywy metrologicznej. Jednak z uwagi na dużą dowolność takiego rozwiązania i brak harmonizacji z dyrektywą MID jest to dosyć ryzykowne zarówno dla producenta, jak i jednostki notyfikowanej (ze względu na możliwość popełnienia błędu przy projektowaniu lub ocenie zgodności) i wiąże się z reguły z wyższymi kosztami przeprowadzenia oceny zgodności.

Prosimy cytować jako Nafta-Gaz 2016, nr 4, s. 262-270, DOI: 10.18668/NG.2016.04.04

Artykuł nadesłano do Redakcji 22.12.2015 r. Zatwierdzono do druku 8.03.2016 r.

\section{Literatura}

[1] Gacek Z.: Ocena zgodności gazomierzy turbinowych przeznaczonych do użytkowania w zakresie ciśnień roboczych powyżej 4 barów. Nafta-Gaz 2013, nr 1, s. 78-83.

[2] Kułaga P.: Ocena zgodności gazomierzy inteligentnych $w$ świetle wymagań dyrektywy metrologicznej. Nafta-Gaz 2014, nr 6, s. $375-382$

[3] Tyszownicka M., Jaworski J.: Wybrane problemy systemu oceny zgodności i prawnej kontroli metrologicznej na przykładzie gazomierzy i przeliczników. Nafta-Gaz 2012, nr 12, s. $1030-1035$.

\section{Akty prawne i normatywne}

[4] Dyrektywa 2004/22/WE Parlamentu Europejskiego i Rady z dnia 31 marca 2004 r. w sprawie przyrządów pomiarowych (Dz.U. UE L 135 z 30.04.2004).

[5] Dyrektywa Parlamentu Europejskiego i Rady 2014/32/UE z dnia 26 lutego 2014 r. w sprawie harmonizacji ustawodawstw państw członkowskich odnoszących się do udostępniania na rynku przyrządów pomiarowych (Dz.U. UE L 96 z 29.03.2014).

[6] Komunikat Komisji w ramach wykonania dyrektywy 2004/22/
WE Parlamentu Europejskiego i Rady w sprawie przyrządów pomiarowych (Dz.U. UE C 76 z 14.03.2014, s. 1-20).

[7] Komunikat Komisji w ramach wykonania dyrektywy 2004/22/ WE Parlamentu Europejskiego i Rady w sprawie przyrządów pomiarowych (Dz.U. UE C 268 z 10.11.2009, s. 4-7).

[8] Komunikat Komisji w ramach wykonania dyrektywy 2004/22/ WE Parlamentu Europejskiego i Rady w sprawie przyrządów pomiarowych (Dz.U. UE C 76 z 14.03.2014, s. 21-22).

[9] PN-EN 12261:2005 wraz z aktualizacją PN-EN 12261:2005/ A1:2008 Gazomierze. Gazomierze turbinowe.

[10] PN-EN 12405-1+A2:2010 Gazomierze. Przeliczniki. Część 1: Przeliczanie objętości.

[11] PN-EN 12480:2015 Gazomierze. Gazomierze rotorowe.

[12] PN-EN 12480:2005 wraz z aktualizacją PN-EN 12480:2005/ A1:2008 Gazomierze. Gazomierze rotorowe.

[13] PN-EN 1359:2004 wraz z aktualizacją PN-EN 1359:2004/ A1:2006 Gazomierze. Gazomierze miechowe.

[14] PN-EN 14236:2010 Gazomierze domowe ultradźwiękowe.

[15] PN-EN 16314:2013 Gazomierze. Dodatkowe funkcjonalności.

[16] PN-ISO 17089-1:2013 Pomiar przepływu płynu w przewodach 
zamkniętych. Gazomierze ultradźwiękowe. Część 1: Gazomierze do pomiarów rozliczeniowych i bilansowych.

[17] Rozporządzenie Ministra Gospodarki z dnia 16 sierpnia $2010 \mathrm{r}$ zmieniające rozporządzenie w sprawie zasadniczych wymagań dla przyrządów pomiarowych (Dz.U. z 2010 r. Nr 163, poz. 1103).

[18] Rozporządzenie Ministra Gospodarki z dnia 18 grudnia 2006 r. w sprawie zasadniczych wymagań dla przyrządów pomiarowych (Dz.U. z 2007 r. Nr 3, poz. 27 z późn. zm.).

[19] Ustawa z dnia 11 maja 2001 r. - Prawo o miarach (Dz.U. z 2001 r. Nr 63, poz. 636 z późn. zm.).

[20] Ustawa $z$ dnia 15 grudnia 2006 r. o zmianie ustawy o systemie oceny zgodności oraz o zmianie niektórych innych ustaw (Dz.U. z 2006 r. Nr 249, poz. 1834).

[21] Ustawa z dnia 27 maja 2004 r. o zmianie ustawy - Prawo o miarach (Dz.U. z 2004 r. Nr 141, poz. 1493).

[22] Ustawa z dnia 30 sierpnia 2002 r. o systemie oceny zgodności (Dz.U. z 2002 r. Nr 166, poz. 1360 z późn. zm.).

[23] Zalecenia Międzynarodowej Organizacji Metrologii Prawnej OIML R 137-1\&2, Edition 2012, Gas meters. Part 1 :
Metrological and technical requirements. Part 2: Metrological controls and performance tests.

[24] Zalecenia Międzynarodowej Organizacji Metrologii Prawnej OIML R 137-1, Edition 2006, Gas meters. Part 1: Requirements.

[25] Zalecenia Międzynarodowej Organizacji Metrologii Prawnej OIML R 137-3:2014, Gas meters. Part 3: Test report format

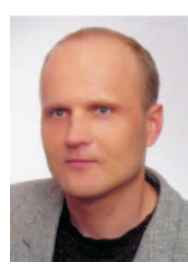

Dr inż. Zbigniew GACEK

Adiunkt w Zakładzie Metrologii Przepływów. Instytut Nafty i Gazu - Państwowy Instytut Badawczy ul. Lubicz 25 A

31-503 Kraków

E-mail: zbigniew.gacek@inig.pl

\section{OFERTA}

\section{ZAKŁAD METROLOGII PRZEPŁYWÓW}

Zakres działania:

- badania gazomierzy, przeliczników objętości, przetworników ciśnienia i temperatury oraz czujników platynowych termometrów rezystancyjnych w ramach akredytacji PCA nr AB041 (w tym na potrzeby oceny zgodności z dyrektywą MID (Moduł B) nr 2004/22/WE - Jednostka Notyfikowana $\mathrm{nr}$ 1450);

» badania gazomierzy rotorowych, zgodnie z PN-EN 12480,

» badania gazomierzy turbinowych, zgodnie z PN-EN 12261,

» badania gazomierzy miechowych, zgodnie z PN-EN 1359 (w tym badania odporności gazomierzy miechowych na działanie magnesów neodymowych),

» badania przeliczników objętości, przetworników ciśnienia i temperatury oraz czujników platynowych termometrów rezystancyjnych, zgodnie z PN-EN 12405-1,

- $\quad$ badania w ramach akredytacji PCA nr AB041 odporności: powłok ochronnych na korozję, na mgłę solną, wilgotność, uderzenie, zarysowanie, odporności chemicznej na ciecze;

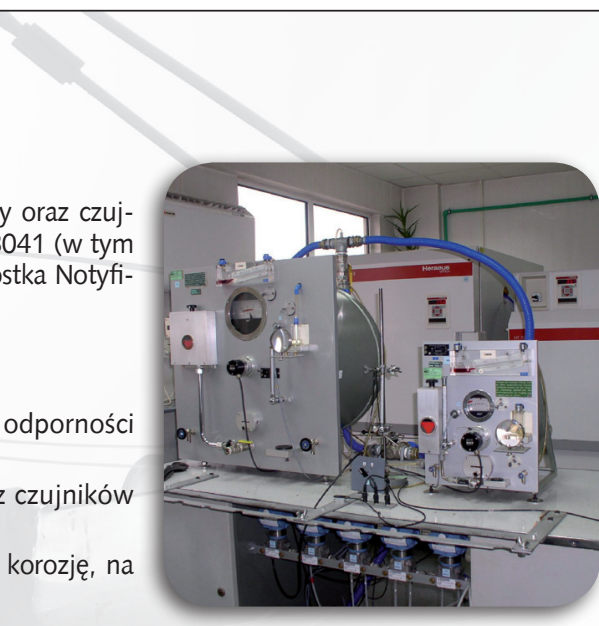

- $\quad$ wzorcowanie przepływomierzy w zakresie od $0,015 \mathrm{~m}^{3} / \mathrm{h}$ do $1000 \mathrm{~m}^{3} / \mathrm{h}$;

- $\quad$ wzorcowanie mierników i kalibratorów wielkości elektrycznych: napięcie DC i AC w zakresie 0-1000 V; natężenie prądu DC i AC w zakresie 0-20 A; rezystancja w zakresie $0 \Omega-20 \mathrm{G} \Omega$

- $\quad$ wzorcowanie ciśnieniomierzy, kalibratorów ciśnienia oraz przetworników i torów pomiaru ciśnienia w zakresie 0-135 bar abs/gauge;

- wzorcowanie czujników termometrów rezystancyjnych, przetworników temperatury, termoelementów, termometrów szklanych cieczowych, termometrów z cyfrowym odczytem temperatury oraz torów pomiaru temperatury w zakresie $-40-660^{\circ} \mathrm{C}$;

- $\quad$ ekspertyzy metrologiczne gazomierzy oraz ekspertyzy pod kątem nielegalnego poboru gazu.

Kierownik: mgr inż. Paweł Kułaga

Adres: ul. Bagrowa 1, 30-733 Kraków

Telefon: 126177426

Faks: 126531665

E-mail: pawel.kulaga@inig.pl 